\title{
Cancerous stem cells: deviant stem cells with cancer-causing misbehavior
}

\author{
Julie M Chandler* and Eric Lagasse*
}

\begin{abstract}
Stem cells maintain homeostasis in adult tissues via self-renewal and generation of terminally differentiated cells. Alterations in this intricate balance can result in disease. It has become increasingly evident that cancer can be initiated at the level of stem cells. Therefore, understanding what causes stem cells to become cancerous may lead to new therapeutic approaches. Multiple signaling pathways ultimately affect stem cell survival and proliferation, thus maintaining homeostasis in the gut. Changes in these pathways could perturb normal stem cell behavior, leading to cancerous stem cells. In addition, cancerous stem cells show resistance to current therapies and may lead to a dangerous selection process resulting in recurrence and metastasis. Genomic instability, the driving force of mutation and resistance, may give cancerous stem cells an adaptive advantage, especially when subjected to cancer therapies. Targeting the unique characteristics of cancerous stem cells to promote either terminal differentiation or destruction would effectively eradicate cancer and improve patient care and survival.
\end{abstract}

\section{Introduction}

Stem cells are a quintessential key to proper behavior of homeostatic processes. They are often thought of as the solution to a wide range of human conditions, with the ability to rescue malfunctioning or non-functioning organs and tissues. However, there is increasing evidence that stem cells can play a central role in disease. Most recently, stem cells have been implicated in cancer after not responding to homeostasic controls, such as

*Correspondence: juc24@pitt.edu or lagasse@pitt.edu

McGowan Institute for Regenerative Medicine, Department of Pathology, University of Pittsburgh Medical School, 450 Technology Drive, Suite 300, Pittsburgh, PA 15219, USA proliferation and differentiation [1]. There are currently two models for the cellular origin of cancer and their lines are becoming blurred as research in the area continues (Figure 1). The hierarchy model identifies a limited number of tumor cells, called cancer stem cells (CSCs), capable of initiating a heterogenous tumor, whereas the stochastic model describes a probability that specific events in a tumor cell population have the potential to transform any tumor cell into a tumor-initiating cell [2,3]. Cancer is the second leading cause of death in the US, and colorectal cancer is the third most common cancer among men and women and accounts for $10 \%$ of all new cancers [4]. Colorectal cancer has been suggested to follow a hierarchy or CSC model, being initiated by a CSC [5], although not all CSCs are derived from stem cells. It is important to note that the CSC hypothesis is still a model for how cancer arises and provides resistance to therapy. This model is supported by experimental evidence [2,6-8] but will need further experimental support, particularly in the context of human cancer. Furthermore, a report by Quintana and colleagues [9] in human melanoma suggests the possibility that not all cancers follow a CSC model. With a severely immunocompromised mouse, $25 \%$ of human tumor cells were tumorigenic, suggesting that tumorigenic cells are more common in some human cancers than previously thought $[9,10]$ and may correspond to what is expected in a stochastic model more than in a hierarchy model. However, the impact and interpretation of studies such as these are still up for discussion [8]. This review will focus on the most recent evidence for the existence of CSCs and their implication in tumorigenesis, metastases, recurrence and therapy resistance using colon cancer as a model system.

\section{Obedient versus defiant stem cells Self-control and homeostasis}

A myriad of cells contribute to the normal function and maintenance of adult tissues. Some cells, such as goblet cells that produce mucus in the colon, play functional roles in specific tissues. These altruistic cells are terminally differentiated and will die serving the tissue. Other rare and undifferentiated cells, called stem cells, 


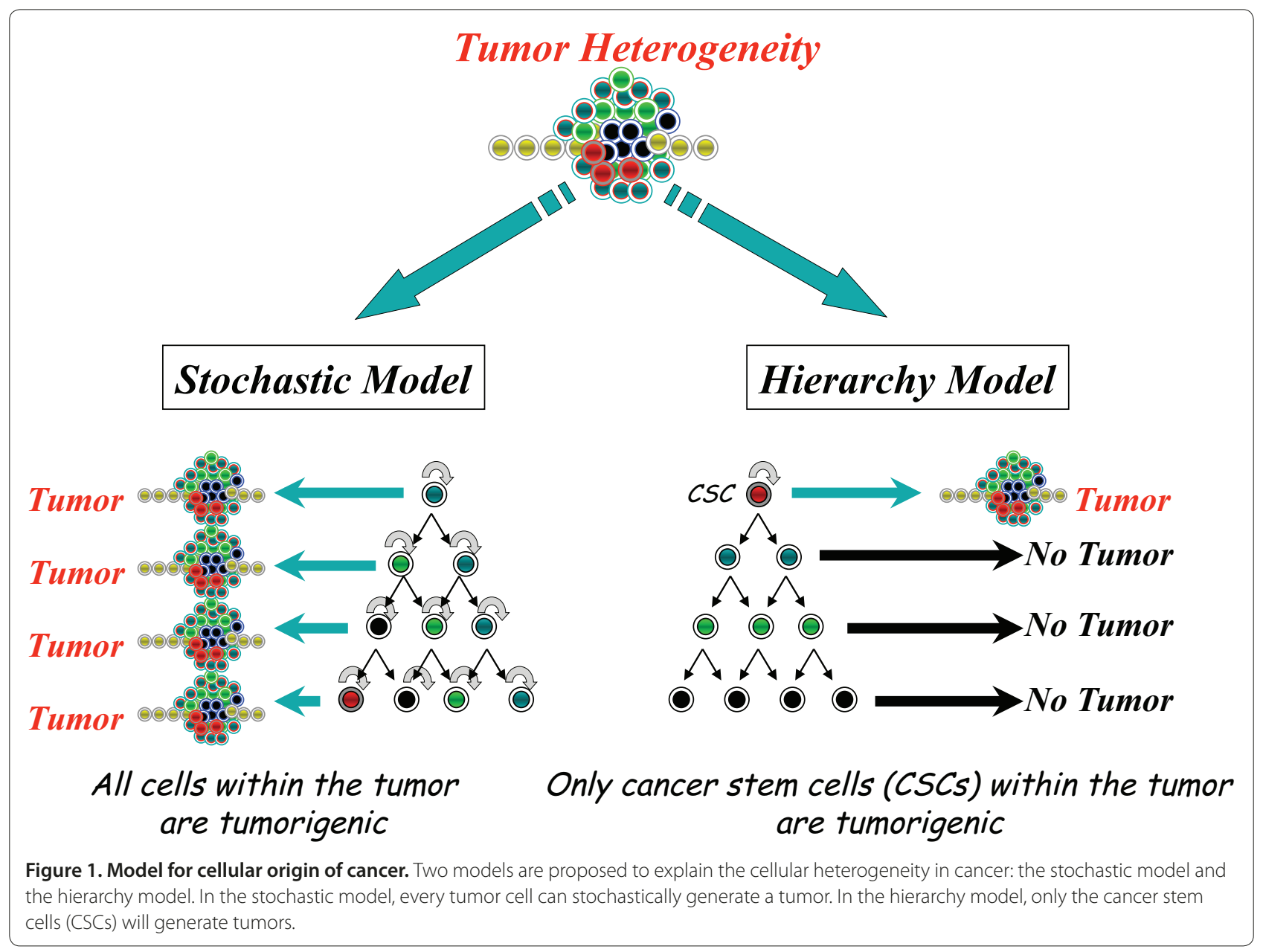

are responsible for replenishing the pool of differentiated cells while maintaining an adequate supply of themselves through the process of self-renewal. Stem cells can divide asymmetrically to produce one daughter cell that is more committed to a specific cell lineage, a transit-amplifying (TA) cell, and one that retains stem-ness. TA cells have a limited life span and self-renewal potential while repopulating the differentiated cells of the tissue.

The colon is organized in this hierarchical fashion and its epithelium is renewed every 5 days in humans [11]. In this very dynamic process lies a complex collection of epithelial cell lineages along with an intricate set of molecular mechanisms to maintain order. To preserve tissue function, the colon is structurally organized in an elegant network of invaginations, termed crypts, which aid in the absorption of water and vitamins. Stem cells of the colon are located at the base of these crypts and produce epithelial cells that are committed to three different cell lineages. These differentiated cells are the absorptive enterocytes, mucus-secreting goblet cells, and hormonal enteroendocrine cells that will migrate up the crypt wall to form the colon (Figure 2).

\section{Defiance and altered management}

Since one of the hallmarks of stem cells is their ability to self-renew and differentiate, investigators were prompted to explore the similarities and differences that exist between normal stem cell maintenance of tissues and organs and the uncontrolled proliferation of cancer [2]. In essence, tumors can be viewed as small aberrant organs containing a hierarchy of progenitor cells and differentiated cells (Figure 2, for example). Albeit dysfunctional when compared to physiologically functioning organs, they maintain their own abnormal proliferation and survival mechanisms [7]. If tumors are indeed aberrant organs, then there is a program by which the system is controlled, however loosely it might be. Therefore, in the cellular hierarchy of a tumor, there is a differentiation mechanism from tumor stem cell to tumor progenitor cell to mature tumor cell which ends in apoptosis and turnover [6]. Abnormal cellular behavior in this tightly controlled system can occur via genetic alterations, such as tumor suppressor loss or gene destabilization, which result in incremental neoplastic gains and disruption of the homeostatic system [12]. 


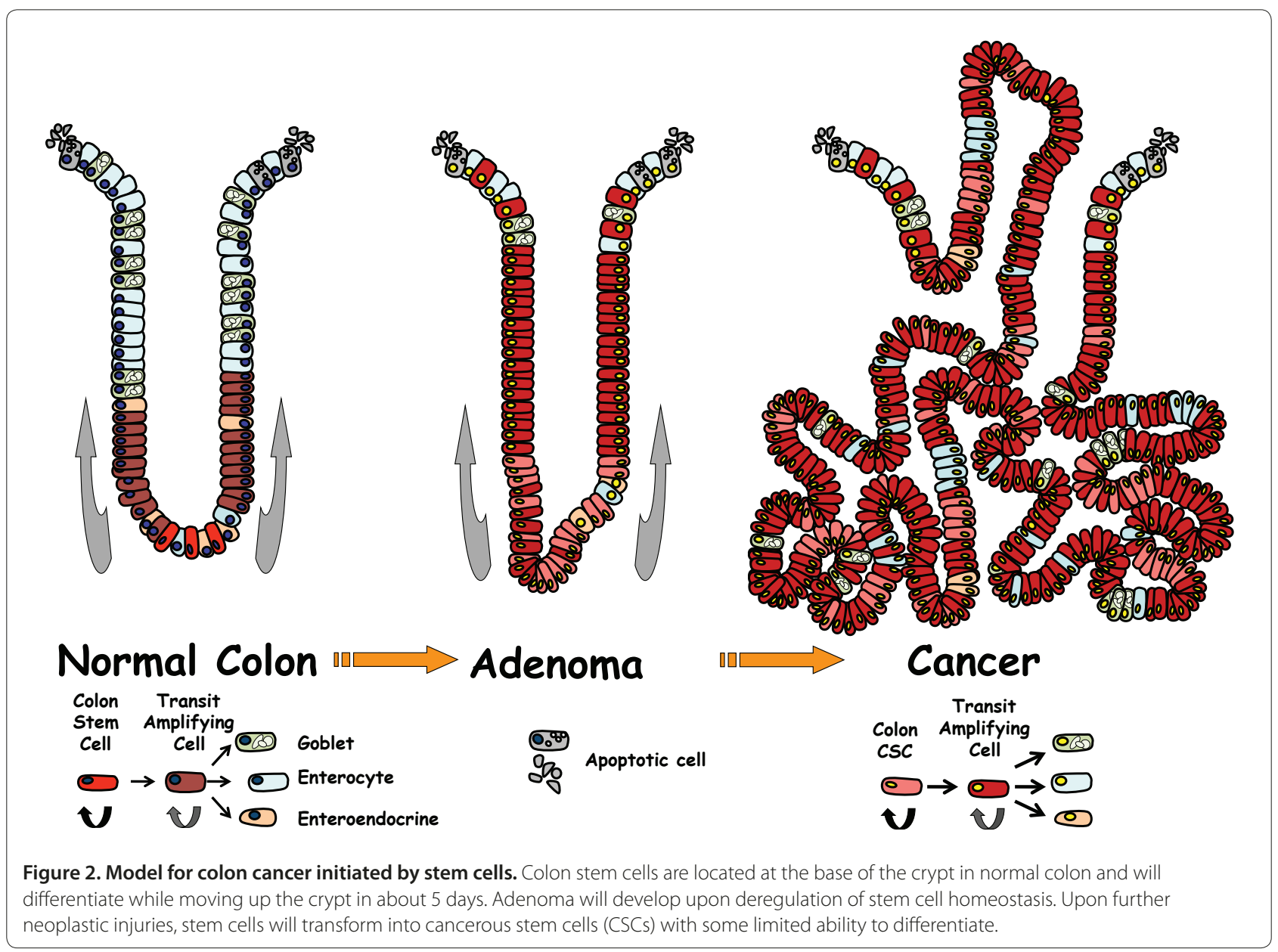

With these alterations, resulting in a loosely controlled system, cancer will eventually prevail. If the alterations can be restricted and coerced to force cells to terminally differentiate and die, the invading neoplastic tissue will cease to exist.

To determine what makes a normal stem cell misbehave, it must first be determined what makes them behave normally. Wnt signaling is one of the driving forces in crypt formation and maintenance of the colon [13]. When Wnt proteins bind Frizzled/LRP receptors, the canonical Wnt pathway ensues. This involves the disruption of the destruction complex that sequesters beta-catenin in the cytoplasm with axin, adenomatous polyposis coli (APC), and glycogen synthase kinase 3 (GSK3) beta. This complex marks beta-catenin for degradation and leads to a decrease in Wnt targeted transcription. When the complex is disrupted, beta-catenin can enter the nucleus and, in concert with transcription factor 4 (TCF4), effect transcription of Wnt targets [14]. The dysregulation of the Wnt pathway and its role in selfrenewal as well as differentiation have been shown to be required for the development of cancer [13]. Deviance in any of these factors will tip the balance toward cancer.
Furthermore, recent in vivo studies in rodents have indicated that colonic crypts are derived from Lgr5 $5^{+}$(leucinerich repeat-containing $G$ protein-coupled receptor 5-positive) crypt base columnar cells. Lineage-tracing assays using Lgr5-lacZ mice indicated that the rare crypt base columnar cells represent the stem cells of the colon [15]. The $\operatorname{Lgr} 5$ gene is a Wnt target and is repressed upon inhibition of the pathway [15]. Therefore, if aberrantly active, the Wnt pathway could result in an expanded progenitor population and colon cancer (Figure 1).

One of the most commonly mutated genes in human colorectal cancer is Apc, which has been implicated in both the sporadic and inherited forms of this cancer [16]. As discussed above, this is one of the players involved in the destruction of beta-catenin. Upon disruption of this protein interaction, beta-catenin is free to roam into the nucleus, where it upsets gene transcription via interactions with transcription factors and subsequently disrupts homeostasis. This concept was nicely demonstrated with $\mathrm{Lgr}^{+}$colon stem cells when Lgr5-EGFP mice with floxed $A p c$ were treated with tamoxifen. The resulting deletion of the $A p c$ gene in the stem cell compartment supported the idea that stem cell-specific 
loss of $A p c$ will result in a progressive neoplasia and eventually cancer [17]. Since some of these transformed cells had retained their Lgr5 expression, Lgr5 $5^{+}$tumor cells could also be considered true CSCs and the Lgr5 epitope as a possible CSC marker (Figure 2).

Parallel to the studies investigating Lgr5 and its role as a stem cell marker of the intestine was the investigation of Bmi1. Bmil is a transcriptional receptor in the polycomb group (PcG) gene family and is involved in stem cell maintenance, proliferation, differentiation to more committed cells, malignant transformation, and biologic aggressiveness of human carcinomas $[18,19]$. It is a member of the PcG proteins and, more specifically, the polycomb-repressing complex 1 (PRC1), indicating a role in maintaining chromatin silencing [20]. As expected, any factor involved in gene silencing has the capacity to exponentially misbehave. If the genes affected are involved in maintaining control, their silencing could perturb the structured environment of a tissue. Bmi1 transcriptionally regulates the INK4a locus encoding $\mathrm{p} 16^{\mathrm{INK} 4 \mathrm{a}}$ and $\mathrm{p} 19^{\mathrm{ARF}}$ tumor suppressors [21]. By suppressing a tumor suppressor, a double-negative results in a positive for cancer growth as well as for the expansion of cells with stem cell properties. Therefore, Bmil became an interesting endeavor for the cancer stem cell biologist. As with Lgr5, a lacZ reporter assay identified Bmi1 as the source for all differentiated cells of the mouse intestine. In addition, its ablation led to crypt loss and adenoma formation upon stable beta-catenin expression in these cells [22]. The relation of Bmil to cancer was further enhanced by expression profiles, which showed that increased Bmil expression correlates with poor clinical survival in patients with colon cancer [23].

Bmil also gives a good example of how epigenetics can influence the initiation or propagation of cancer or both. Epigenetic modifications can result in altered signaling and function, thus contributing to the formation or progression of cancer or both [24]. Being a PcG protein, Bmil coordinates the regulation of histone modification and methylation, adding a layer of epigenetic modification to its already existing regulatory role. As seen in breast cancer, Bmil overexpression can block terminal differentiation, leading to an expansion of cells capable of self-renewing [19]. Normally, Bmi1 is lowly expressed in differentiated cells and highly expressed in stem cells. The increased expression of PcG proteins in metastatic breast and prostate cancer occurs in a pool of cancer cells with stem cell-like properties, indicating that this alteration may occur in the CSC population [25].

Although the studies on Lgr5 and Bmi1 suggest that the transformation of stem cells from obedient to deviant cells may lead to tumorigenesis, complete molecular mechanisms have yet to be resolved. Understanding the steps by which stem cell homeostasis is lost and cancer is initiated would pave the way for possible cancer treatments. The Hedgehog-Gli (HH-Gli) signaling pathway is proposed as a mechanism through which normal stem cell maintenance can be dysregulated, leading to colon cancer [26]. In an active HH pathway, Patched is blocked, releasing Smoothened to activate Gli. Although colon cancers and their stem cells of all stages have active HH-Gli signaling, an increase in HH-Gli signaling is seen in metastases. This may indicate that while APC/betacatenin signaling disruption may be the first of many hits toward colon cancer, HH-Gli may be an added push toward deviance [27].

In addition to these pathways, other signaling mechanisms involved in normal stem cell function and homeostasis may contribute to the misbehavior evident in cancer and its stem cells. These include the phosphatase and tensin homolog (PTEN) and Notch pathways [28]. PTEN is a tumor suppressor whereas the Notch pathway regulates cell fate decisions [29,30]. PTEN not only has been implicated in the signaling of CSCs themselves but also has been found in stromal cells of the surrounding tumor microenvironment. The genetic inactivation of Pten in stromal fibroblasts was shown to accelerate the initiation, progression, and malignant transformation of mammary epithelial tumors in mice, a phenotype that was correlated with a specific PTEN signature in patients with breast cancer [31].

\section{Identifying the culprit in human cancer}

Unfortunately, identifying CSCs in human cancers has remained challenging. CD133, a cell surface marker for many normal stem cells, has been thought of as a CSC marker in human cancers, and particularly in human colon cancer, with some controversy about whether it marks the true stem cell population. Using the AC133 antibody to identify CD133 expression, Ricci-Vitiani and colleagues [32] and O'Brien and colleagues [33] both showed in 2007 that it is the $\mathrm{CD}_{133^{+}}$population of human colon cancer cells which initiates the tumor whereas the $\mathrm{CD} 133^{-}$population does not. It seems that such a strong correlation would evoke some sort of function of CD133 to the cancer-initiating cells. However, upon siRNA (short interfering RNA) knockdown, there was no impact on proliferation, migration, colony formation, or invasion, indicating that while CD133 may serve as a prognostic marker of colon cancer and its stem cells, it is not a feasible target to eradicate the troublesome cells [34]. Importantly, the $\mathrm{CD} 133^{+}$population of tumor cells was found to rely on HH-Gli signaling for survival and self-renewal as well as expansion driven by increased signaling [27]. Therefore, even though CD133 expression itself does not seem to affect the tumor's properties, it may be able to identify the cells with aberrant signaling. Adding to the controversy, the 
antibody used to identify CD133, clone AC133, recognizes a glycosylated epitope on the human CD133 antigen. Furthermore, AC133 is not present on all colon cancers and is lost upon differentiation whereas CD133 is not [35-37].

The epithelial cell adhesion molecule (EpCAM) is another claimed CSC marker that has been implicated in stem cell signaling via the Wnt pathway [38]. While EpCAM presence is abundant in the membrane of normal epithelial tissues, it is prone to cleavage in cancer tissue, making it difficult to use as a target [39]. CD44 is also described as a molecule whose splicing variants were shown to be differentially expressed between normal stem cells and CSCs [40]. In combination with CD133, CD44 and CD166 may provide a better way to identify the CSC population. However, this makes therapeutic targeting a challenge because of the heterogenous expression of these markers. Colorectal carcinomas assayed for expression of these markers found that CD133 held the strongest single-marker adverse correlation with patient survival. While CD166 and CD44 alone may have little or no correlation with survival, their combined analysis with CD133 may allow the separation of low-, intermediate-, and high-risk colorectal cancers [41].

\section{Control or destroy?}

So how do we control the CSCs? To date, colon cancer treatments have often resulted in recurrence and metastases. One reason may be that CSCs are more resistant to chemotherapy treatments than their more differentiated progeny are, allowing recurrence and metastases. Therefore, therapies that target either the terminal differentiation or destruction of CSCs must be developed $[28,42,43]$. There have been great efforts to treat acute promyelocytic leukemia with all-trans retinoic acid (ATRA), which acts to differentiate leukemic promyelocytes to normal, terminally differentiated neutrophils [44]. It is thought that such a differentiation therapy may be beneficial in the emerging population of solid cancers that arise from malfunctioning CSCs. The differentiation theory would cause CSCs to lose their dangerous edge: the ability to self-renew [7]. Another approach would be to destroy CSCs directly by harnessing the pathways used for CSC maintenance and survival $[45,46]$.

\section{What do we know?}

A recent study of colon cancer examined FOLFOX (folinic acid, 5-fluorouracil plus oxaliplatin), a widely used treatment for colon cancer [47]. In that study, initial treatment of colon cancer cells enriched the population for $\mathrm{CD}_{133^{+}}, \mathrm{CD}_{4} 4^{+}$, and/or CD166 ${ }^{+}$cells with increased levels of epidermal growth factor receptor-positive $\left(E G^{+}\right)$. Upon subsequent treatment of the surviving cells (the CSCs) with curcumin or curcumin plus
FOLFOX, a reduction in CSCs was seen. Although the mechanism is not fully understood, it was shown to increase methylation of the EGFR promoter. This hypermethylation, via changes in the level of DNA methyltransferase 1, decreases the expression of EGFR, stabilizing the chromatin and preventing the binding of transcription factors [47]. While this may be a desired effect, care must be taken to investigate possible detrimental effects of this type of treatment. Hypermethylation is also known to inactivate the transcription factor $\mathrm{p} 16^{\mathrm{INK4a}}$ [47]. As discussed previously, increased Bmil expression leads to inactivation of $\mathrm{p} 16^{\mathrm{INK4a}}$. Therefore, a therapy that may promote hypermethylation and gene silencing may cause additional imbalances in the already mischievous CSCs.

Recent drug screenings revealed salinomycin as a specific inhibitor of CSCs. This study focused on breast cancer and used $\mathrm{CD} 44^{\text {high }} / \mathrm{CD} 24^{\text {low }}$ as the molecular profile of CSCs. They found that the number of these cells decreased with salinomycin treatment as compared with a current treatment of paclitaxel. Surprisingly, paclitaxel actually increased the number of CSCs. In addition, there was a decrease in tumor sphere formation as well as decreased metastases over paclitaxel [48]. Although this study used breast cancer as a model, colon cancer has been shown to be resistant to paclitaxel. Modifications that include the use of a mitogen-activated protein kinase (MAPK) inhibitor in combination with paclitaxel to enhance apoptosis of colon cancer cells have been suggested [49]. In light of the results in breast cancer, it may be beneficial to investigate the selection of colon CSCs by treatment with paclitaxel. Such a treatment may give a survival advantage that results in a more invasive and aggressive cancer. This is especially true given that salinomycin has been shown to induce apoptosis as well as overcome apoptotic resistance in breast cancer cells [50]. There is a strong connection between colon and breast cancer because they are both epithelial cancers that resemble the tissue of origin, even at metastatic sites.

Drug screenings such as those mentioned above do not take into consideration or define the mechanisms by which the drug has affected the CSC population or the tumor as a whole. Several other studies have used what is known about stem cell and CSC signaling, discussed above, to target CSCs. The HH pathway is active in both bulk and stem cell populations of a tumor and therefore it may represent a mechanism that can be targeted for therapy. One study showed that cyclopamine, an $\mathrm{HH}$ inhibitor, could increase apoptosis and decrease proliferation [51]. In addition, the manipulation of the Notch pathway via drug intervention may successfully target CSCs. Gamma-secretase inhibitors have been shown to reduce cancer growth, inhibit CSC self-renewal, and increase differentiation to goblet cells [52,53]. Similar 
results were found with small-molecule and RNA knockdown studies showing that the inhibition of Notch leads to increased apoptotsis, decreased self-renewal, and increased secretory cell lineage differentiation of CSCs in colon cancer [54]. In yet another study focusing on the Notch pathway, inhibition of Delta-like ligand 4 (DLL4) inhibited the expression of Notch targets and reduced tumor-initiating cell frequency [55]. These targeted therapies may enhance the efficacy of chemotherapeutic drugs when used in sequence or combination [46]. However, one must realize that these are mechanisms shared by normal intestinal stem cells and may lead to toxicity.

While there are treatments that seem to reduce the number of CSCs, two problems remain. Just reducing the population of misbehaving cells does not solve the problem. As soon as the treatment ceases, these cells can again flourish. Unfortunately, thus far, there has been no demonstration that targeting CSCs will improve the outcome of patients with cancer.

\section{Peer pressure: the mastermind}

If stem cells are indeed the culprit behind colon cancer and alterations in their behavior are the driving force, what causes the alterations? The answer may be genomic instability (GI), which could explain why colon cancer remains such a difficult disease to treat despite the breadth of knowledge obtained over recent years. GI occurring in stem cells may be one of the initiating peer pressure events that drive normal stem cells to go awry and become CSCs [56-58]. If it is not an initiating event, GI may be the result of other alterations, thus steering the stem cell population into cancer. Chromosomal aberrations and DNA repair mutations affecting migration and proliferation in these cells lead to metastases and cancers that are more aggressive [59]. In addition to carcinogenesis and disease progression, GI may be responsible for resistance to current therapies making colon cancer such a devastating disease [60]. As mentioned previously, current therapies may effectively treat the bulk tumor but, in effect, could select for the more tumorigenic CSCs. If this is the cell population that harbors GI, these cells are more likely to evade the toxic effects of cancer drugs by adaptations that only their instability has allowed. In essence, natural selection selects not only the fittest organisms but also the fittest cells $[5,36]$. After the selective therapy has occurred, the population of the fittest cells, which includes those with enhanced abilities to migrate and proliferate, expands. Even with a change in treatment regimen, GI continues to perpetuate the peer pressure to become adaptively deviant, resulting in a cancer without restraint.

Two types of GI are present in colon cancer: microsatellite instability (MSI) and chromosomal instability (CIN). MSI refers to genetic or epigenetic alterations or both in DNA mismatch repair mechanisms, including MSH2 and MLH1, which can lead to loose control of DNA metabolism and cell cycle control and result in carcinogenesis [56,57]. This results in a nucleotide mutation rate that is two to three orders of magnitude greater than that of normal cells [56]. MSI in tumors may determine site-related differences when comparing proximal and distal colon tumors; therefore, MSI-bearing tumors are unique and may be indicative of a class of tumors more prone to genetic alterations and adaptations [61]. Surprisingly, MSI tumors are associated with a better prognosis and are less prone to metastasis than their microsatellite-stable (MSS) counterparts [62]. The mechanism behind this phenomenon in MSI involves a mutation in transforming growth factor-beta receptor 2 and the resulting inability to undergo epithelial-mesenchymal-transition (EMT) as seen with MSS tumors [63]. EMT is often associated with the ability of cancers to metastasize and therefore leads to a poorer prognosis [64]. Such results indicate that GI may not always support cancer progression and the use of MSI status for prognosis or therapy response or both has the potential to improve patient care $[58,65]$. In addition, the information obtained from MSI tumors may unveil ways to harness MSS tumors.

While colon cancers with MSI make up only a small portion of cases, most of the remaining colon cancers exhibit CIN involving an increased tendency for gain or loss of chromosomes in part or whole [66]. While seemingly minor mutations resulting from MSI have been linked to colon cancer, CIN has been linked to the previously mentioned $A p c$ mutations commonly seen in colon cancer. Prior to the beta-catenin dysregulation that results in increased self-renewal, altered APC-mediated microtubule regulation may be the first point of deviance. The mitotic infidelity at this point places CIN earlier in carcinogenesis progression that may determine the future of a particular colon cancer and has been correlated with poor prognosis $[67,68]$. As a consequence of APC deletion, the calcium gradient present in the crypts of the colon is perturbed [69]. Normally, $\mathrm{Ca}^{+2}$ concentrations increase as cells migrate up the crypt. This is paralleled by an increased expression of the calcium-sensing receptors (CaSRs) and consequential E-cadherin expression. This normal process drives terminal differentiation and apoptosis at the crypt mucosal surface. In cases in which APC is lost, an expansion of TA cells below the $\mathrm{Ca}^{+2}$ gradient change leads to a pool of proliferating cells that cannot express CaSR, thus perpetuating or even accelerating the development of disease [70,71]. While it seems as though colon cancer will prevail, targeting its GI could be an Achilles heel for treatment.

Although GI can be considered the driving force for cancer, more importantly, it is the sustained force that 


\section{Challenges and Future Directions}

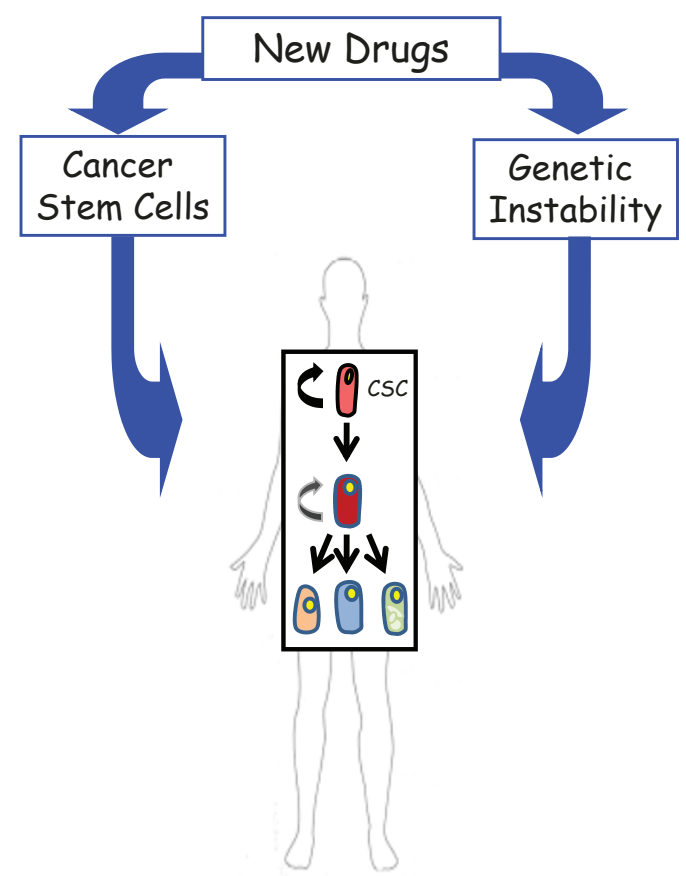

Figure 3. Potential approach to cure cancer. A combined approach to target both the tumor-initiating cell (cancer stem cell or CSC) and its driving force (genomic instability) is proposed for the best outcome in patients with cancer.

may provide CSCs with the ability to evade treatment [68]. If CSCs can be targeted by approaches that are more specific, the fact that GI is also present in these CSCs will make them moving targets [60]. As a consequence, both the specific targeting of CSCs and the inhibition of GI appear to be necessary for a successful approach to eradicating cancer in patients.

\section{Conclusions}

In colon cancer, like many other cancers, it seems that Mother Nature used two of its best creations, stem cells and GI, to produce tumor cells with survival skills unmatched by any other cells. Pathways such as Wnt, Notch, and HH may be potential therapeutic targets to force control of CSCs, but owing to GI, these approaches may subsequently find resistance. Therefore, treatments that are specific to both CSCs and GI may be the only solution to this difficult problem (Figure 3). Only when all CSCs are eradicated via either destruction or terminal differentiation will cancer be truly cured. However, much still needs to be understood about normal stem cell versus CSC function and maintenance before effective treatments can be generated for such defiant cellular mechanisms.

\section{Abbreviations}

APC, adenomatous polyposis coli; CaSR, calcium-sensing receptor; CIN, chromosomal instability; CSC, cancer stem cell or cancerous stem cell; EGFR, epidermal growth factor receptor; EMT, epithelial-mesenchymal-transition; EpCAM, epithelial cell adhesion molecule; FOLFOX, folinic acid, 5-fluorouracil plus oxaliplatin; Gl, genomic instability; HH, Hedgehog; Lgr5, leucine-rich repeat-containing G protein-coupled receptor 5; MSI, microsatellite instability; MSS, microsatellite-stable; PCG, polycomb group; PTEN, phosphatase and tensin homolog; TA, transit amplifying.

\section{Competing interests}

The authors declare that they have no competing interests.

\section{Acknowledgments}

This work was supported by the Jeannik M Littlefield-American Association for Cancer Research (EL) and Cellular Approaches to Tissue Engineering and Regeneration-National Institutes of Health grant support 2 T32 EB001026-06) (JC). The authors thank Lindsey Boone and Aaron DeWard for their comments.

Published: 20 May 2010

\section{References}

1. Buick RN, Pollak MN: Perspectives on clonogenic tumor cells, stem cells, and oncogenes. Cancer Res 1984, 44:4909-4918.

2. Reya T, Morrison SJ, Clarke MF, Weissman IL: Stem cells, cancer, and cancer stem cells. Nature 2001, 414:105-111.

3. Dick JE: Looking ahead in cancer stem cell research. Nat Biotechno/ 2009, 27:44-46.

4. Jemal A, Siegel R, Ward E, Hao Y, Xu J, Thun MJ: Cancer statistics, 2009. CA Cancer J Clin 2009, 59:225-249.

5. Odoux C, Fohrer H, Hoppo T, Guzik L, Stolz DB, Lewis DW, Gollin SM, Gamblin TC, Geller DA, Lagasse E: A stochastic model for cancer stem cell origin in metastatic colon cancer. Cancer Res 2008, 68:6932-6941.

6. Al-Hajj M, Clarke MF: Self-renewal and solid tumor stem cells. Oncogene 2004, 23:7274-7282.

7. Sell S: Stem cell origin of cancer and differentiation therapy. Crit Rev Oncol Hemato/ 2004, 51:1-28

8. Shackleton M, Quintana E, Fearon ER, Morrison SJ: Heterogeneity in cancer: cancer stem cells versus clonal evolution. Cell 2009, 138:822-829.

9. Quintana E, Shackleton M, Sabel MS, Fullen DR, Johnson TM, Morrison SJ: Efficient tumour formation by single human melanoma cells. Nature 2008, 456:593-598.

10. Schatton T, Murphy GF, Frank NY, Yamaura K, Waaga-Gasser AM, Gasser M, Zhan Q, Jordan S, Duncan LM, Weishaupt C, Fuhlbrigge RC, Kupper TS, Sayegh MH, Frank MH: Identification of cells initiating human melanomas. Nature 2008, 451:345-349.

11. Potten CS, Kellett M, Roberts SA, Rew DA, Wilson GD: Measurement of in vivo proliferation in human colorectal mucosa using bromodeoxyuridine. Gut 1992, 33:71-78.

12. Vogelstein B, Kinzler KW: Cancer genes and the pathways they control. Nat Med 2004, 10:789-799.

13. Korinek V, Barker N, Moerer P, van Donselaar E, Huls G, Peters PJ, Clevers H: Depletion of epithelial stem-cell compartments in the small intestine of mice lacking Tcf-4. Nat Genet 1998, 19:379-383.

14. Clevers $\mathrm{H}$ : Wnt/beta-catenin signaling in development and disease. Cell 2006, 127:469-480.

15. Barker N, van Es JH, Kuipers J, Kujala P, van den Born M, Cozijnsen M, Haegebarth A, Korving J, Begthel H, Peters PJ, Clevers H: Identification of stem cells in small intestine and colon by marker gene Lgr5. Nature 2007, 449:1003-1007.

16. Kwong LN, Dove WF: APC and its modifiers in colon cancer. Adv Exp Med Biol 2009, 656:85-106.

17. Barker N, Ridgway RA, van Es JH, van de Wetering $M$, Begthel $H$, van den Born M, Danenberg E, Clarke AR, Sansom OJ, Clevers H: Crypt stem cells as the cells-of-origin of intestinal cancer. Nature 2009, 457:608-611.

18. Park IK, Morrison SJ, Clarke MF: Bmi1, stem cells, and senescence regulation. J Clin Invest 2004, 113:175-179.

19. Pietersen AM, Evers B, Prasad AA, Tanger E, Cornelissen-Steijger P, Jonkers J, van Lohuizen $\mathrm{M}: \mathrm{Bmi} 1$ regulates stem cells and proliferation and differentiation of committed cells in mammary epithelium. Curr Biol 2008, 18:1094-1099. 
20. Valk-Lingbeek ME, Bruggeman SW, van Lohuizen M: Stem cells and cancer; the polycomb connection. Cell 2004, 118:409-418.

21. Jacobs JJ, Kieboom K, Marino S, DePinho RA, van Lohuizen M: The oncogene and Polycomb-group gene bmi-1 regulates cell proliferation and senescence through the ink4a locus. Nature 1999, 397:164-168.

22. Sangiorgi $E$, Capecchi $M R: B m i 1$ is expressed in vivo in intestinal stem cells. Nat Genet 2008, 40:915-920

23. $\mathrm{Du} J, \mathrm{Li} Y, \mathrm{Li} J$, Zheng J: Polycomb group protein Bmi1 expression in colon cancers predicts the survival. Med Oncol 2009 Dec 1. [Epub ahead of print].

24. Feinberg AP: Phenotypic plasticity and the epigenetics of human disease. Nature 2007, 447:433-440.

25. Mathews LA, Crea F, Farrar WL: Epigenetic gene regulation in stem cells and correlation to cancer. Differentiation 2009, 78:1-17.

26. Gulino A, Ferretti E, De Smaele E: Hedgehog signalling in colon cancer and stem cells. EMBO Mol Med 2009, 1:300-302.

27. Varnat F, Duquet A, Malerba M, Zbinden M, Mas C, Gervaz P, Ruiz i Altaba A: Human colon cancer epithelial cells harbour active HEDGEHOG-GLI signalling that is essential for tumour growth, recurrence, metastasis and stem cell survival and expansion. EMBO Mo/ Med 2009, 1:338-351.

28. Massard C, Deutsch E, Soria JC: Tumour stem cell-targeted treatment: elimination or differentiation. Ann Oncol 2006, 17:1620-1624.

29. Myers MP, Pass I, Batty IH, Van der Kaay J, Stolarov JP, Hemmings BA, Wigler $\mathrm{MH}$, Downes CP, Tonks NK: The lipid phosphatase activity of PTEN is critical for its tumor supressor function. Proc Natl Acad Sci U S A 1998, 95:13513-13518

30. Artavanis-Tsakonas S, Rand MD, Lake RJ: Notch signaling: cell fate control and signal integration in development. Science 1999, 284:770-776.

31. Trimboli AJ, Cantemir-Stone CZ, Li F, Wallace JA, Merchant A, Creasap N, Thompson JC, Caserta E, Wang H, Chong JL, Naidu S, Wei G, Sharma SM, Stephens JA, Fernandez SA, Gurcan MN, Weinstein MB, Barsky SH, Yee L, Rosol TJ, Stromberg PC, Robinson ML, Pepin F, Hallett M, Park M, Ostrowski MC, Leone G: Pten in stromal fibroblasts suppresses mammary epithelial tumours. Nature 2009, 461:1084-1091.

32. Ricci-Vitiani L, Lombardi DG, Pilozzi E, Biffoni M, Todaro M, Peschle C, De Maria $R$ : Identification and expansion of human colon-cancer-initiating cells. Nature 2007, 445:111-115.

33. O'Brien CA, Pollett A, Gallinger S, Dick JE: A human colon cancer cell capable of initiating tumour growth in immunodeficient mice. Nature 2007, 445:106-110.

34. Horst D, Scheel SK, Liebmann S, Neumann J, Maatz S, Kirchner T, Jung A: The cancer stem cell marker CD133 has high prognostic impact but unknown functional relevance for the metastasis of human colon cancer. J Pathol 2009, 219:427-434

35. Kemper K, Sprick MR, de Bree M, Scopelliti A, Vermeulen L, Hoek M, Zeilstra J, Pals ST, Mehmet H, Stassi G, Medema JP: The AC133 epitope, but not the CD133 protein, is lost upon cancer stem cell differentiation. Cancer Res 2010, 70:719-729.

36. Lagasse E: Cancer stem cells with genetic instability: the best vehicle with the best engine for cancer. Gene Ther 2008, 15:136-142.

37. Taieb N, Maresca M, Guo XJ, Garmy N, Fantini J, Yahi N: The first extracellular domain of the tumour stem cell marker CD133 contains an antigenic ganglioside-binding motif. Cancer Lett 2009, 278:164-173.

38. Munz M, Baeuerle PA, Gires $\mathrm{O}$ : The emerging role of EpCAM in cancer and stem cell signaling. Cancer Res 2009, 69:5627-5629.

39. Maetzel D, Denzel S, Mack B, Canis M, Went P, Benk M, Kieu C, Papior P, Baeuerle PA, Munz M, Gires O: Nuclear signalling by tumour-associated antigen EpCAM. Nat Cell Biol 2009, 11:162-171.

40. Miletti-Gonzalez KE, Chen S, Muthukumaran N, Saglimbeni GN, Wu X, Yang J, Apolito K, Shih WJ, Hait WN, Rodriguez-Rodriguez L: The CD44 receptor interacts with P-glycoprotein to promote cell migration and invasion in cancer. Cancer Res 2005, 65:6660-6667.

41. Horst D, Kriegl L, Engel J, Kirchner T, Jung A: Prognostic significance of the cancer stem cell markers CD133, CD44, and CD166 in colorectal cancer. Cancer Invest 2009, 27:844-850.

42. Pierce GB: The cancer cell and its control by the embryo. Rous-Whipple Award lecture. Am J Pathol 1983, 113:117-124.

43. Spira Al, Carducci MA: Differentiation therapy. Curr Opin Pharmacol 2003, 3:338-343.

44. Wang $Z Y$, Chen $Z$ : Acute promyelocytic leukemia: from highly fatal to highly curable. Blood 2008, 111:2505-2515.

45. Gupta R, Vyas P, Enver T: Molecular targeting of cancer stem cells. Cell Stem Cell 2009, 5:125-126.
46. Thenappan A, LiY, Shetty K, Johnson L, Reddy EP, Mishra L: New Therapeutics Targeting Colon Cancer Stem Cells. Curr Colorectal Cancer Rep 2009, 5:209.

47. Yu Y, Kanwar SS, Patel BB, Nautiyal J, Sarkar FH, Majumdar AP: Elimination of Colon Cancer Stem-Like Cells by the Combination of Curcumin and FOLFOX. Transl Oncol 2009, 2:321-328.

48. Gupta PB, Onder TT, Jiang G, Tao K, Kuperwasser C, Weinberg RA, Lander ES: Identification of selective inhibitors of cancer stem cells by highthroughput screening. Cell 2009, 138:645-659.

49. Xu R, Sato N, Yanai K, Akiyoshi T, Nagai S, Wada J, Koga K, Mibu R, Nakamura M, Katano M: Enhancement of paclitaxel-induced apoptosis by inhibition of mitogen-activated protein kinase pathway in colon cancer cells. Anticancer Res 2009, 29:261-270.

50. Fuchs D, Heinold A, Opelz G, Daniel V, Naujokat C: Salinomycin induces apoptosis and overcomes apoptosis resistance in human cancer cells. Biochem Biophys Res Commun 2009, 390:743-749.

51. van den Brink GR, Bleuming SA, Hardwick JC, Schepman BL, Offerhaus GJ, Keller JJ, Nielsen C, Gaffield W, van Deventer SJ, Roberts DJ, Peppelenbosch MP: Indian Hedgehog is an antagonist of Wnt signaling in colonic epithelial cell differentiation. Nat Genet 2004, 36:277-282.

52. Cheng T: Cell cycle inhibitors in normal and tumor stem cells. Oncogene 2004, 23:7256-7266.

53. van Es JH, van Gijn ME, Riccio O, van den Born M, Vooijs M, Begthel $H$, Cozijnsen M, Robine S, Winton DJ, Radtke F, Clevers H: Notch/gammasecretase inhibition turns proliferative cells in intestinal crypts and adenomas into goblet cells. Nature 2005, 435:959-963.

54. Sikandar SS, Pate KT, Anderson S, Dizon D, Edwards RA, Waterman ML, Lipkin SM: NOTCH signaling is required for formation and self-renewal of tumorinitiating cells and for repression of secretory cell differentiation in colon cancer. Cancer Res 2010, 70:1469-1478.

55. Hoey T, Yen WC, Axelrod F, Basi J, Donigian L, Dylla S, Fitch-Bruhns M, Lazetic S, Park IK, Sato A, Satyal S, Wang X, Clarke MF, Lewicki J, Gurney A: DLL4 blockade inhibits tumor growth and reduces tumor-initiating cell frequency. Cell Stem Cell 2009, 5:168-177.

56. Boyer JC, Umar A, Risinger JI, Lipford JR, Kane M, Yin S, Barrett JC, Kolodner RD, Kunkel TA: Microsatellite instability, mismatch repair deficiency, and genetic defects in human cancer cell lines. Cancer Res 1995, 55:6063-6070.

57. Loeb LA: A mutator phenotype in cancer. Cancer Res 2001, 61:3230-3239.

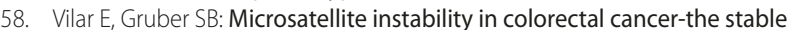
evidence. Nat Rev Clin Oncol 2010, 7:153-162.

59. Zeitoun G: [Cellular and molecular deregulations driving the metastatic phenotype]. Med Sci (Paris) 2009, 25 Spec No 1:29-32.

60. Greaves M: Cancer stem cells: back to Darwin? Semin Cancer Bio/ 2010 Mar 30. [Epub ahead of print].

61. Zhao Y, Oki E, Ando K, Morita M, Kakeji Y, Maehara Y: The impact of a highfrequency microsatellite instability phenotype on the tumor location-related genetic differences in colorectal cancer. Cancer Genet Cytogenet, 196:133-139.

62. Gryfe R, Kim H, Hsieh ET, Aronson MD, Holowaty EJ, Bull SB, Redston M, Gallinger S: Tumor microsatellite instability and clinical outcome in young patients with colorectal cancer. NEngl J Med 2000, 342:69-77.

63. Pino MS, Kikuchi H, Zeng M, Herraiz M-T, Sperduti I, Berger D, Park D-y, lafrate AJ, Zukerberg LR, Chung DC: Epithelial to mesenchymal transition is impaired in colon cancer cells with microsatellite instability. Gastroenterology 2010, 138:1406-1417

64. Mani SA, Guo W, Liao MJ, Eaton EN, Ayyanan A, Zhou AY, Brooks M, Reinhard F, Zhang CC, Shipitsin M, Campbell LL, Polyak K, Brisken C, Yang J, Weinberg RA: The epithelial-mesenchymal transition generates cells with properties of stem cells. Cell 2008, 133:704-715.

65. De Grassi A, Segala C, lannelli F, Volorio S, Bertario L, Radice P, Bernard L, Ciccarelli FD: Ultradeep sequencing of a human ultraconserved region reveals somatic and constitutional genomic instability. PLOS Bio/ 2010, 8:e1000275

66. Lengauer C, Kinzler KW, Vogelstein B: Genetic instabilities in human cancers. Nature 1998, 396:643-649.

67. Caldwell CM, Kaplan KB: The role of APC in mitosis and in chromosome instability. Adv Exp Med Biol 2009, 656:51-64.

68. Thompson SL, Bakhoum SF, Compton DA: Mechanisms of chromosomal instability. Curr Bio/ 2010, 20:R285-295.

69. Sansom OJ, Reed KR, Hayes AJ, Ireland H, Brinkmann H, Newton IP, Batlle E, Simon-Assmann P, Clevers H, Nathke IS, Clarke AR, Winton DJ: Loss of Apc in vivo immediately perturbs Wnt signaling, differentiation, and migration. Genes Dev 2004, 18:1385-1390 
70. Whitfield JF: Calcium, calcium-sensing receptor and colon cancer. Cancer Lett 2009, 275:9-16.

71. Chakrabarty S, Wang H, Canaff L, Hendy GN, Appelman H, Varani J: Calcium sensing receptor in human colon carcinoma: interaction with $\mathrm{Ca}(2+)$ and 1,25-dihydroxyvitamin D(3). Cancer Res 2005, 65:493-498. doi:10.1186/scrt13

Cite this article as: Chandler JM, Lagasse E: Cancerous stem cells: deviant stem cells with cancer-causing misbehavior. Stem Cell Research \& Therapy 2010, 1:13. 